\section{Chromosomal Re-arrangements in the Progeny of Drosophila Males treated with Mustard Gas}

WHEN Drosophila males are treated with mustard gas, the proportion of chromosome re-arrangements to sex-linked lethals in their progeny is lower than after an X-ray treatment which yields the same frequency of sex-linked lethals. This observation has been made by genetical methods ${ }^{1}$. It has been confirmed by the cytological findings of Slizynska and Slizynski2, who examined the salivary chromosomes of strains carrying sex-linked lethals induced by mustard gas and reported that these chromosomes had many fewer structural changes than would have been expected if the lethals had been induced by $\mathrm{X}$-rays. Since these investigations were based on selected samples of chromosomes-namely, $X$-chromosomes already shown to carry a lethal--it seemed important to check them on unselected samples. Accordingly, wild-type Drosophila males were given different doses of mustard gas, and unselected female $F_{1}$ larvæ were analysed for chromosomal changes in their salivary glands. The apparatus for the treatment was designed by Dr. H. Moser and has been described elsewhere ${ }^{3}$. The genetical effectivenoss of each dose was measured in terms of sex-linked lethals. For comparison, exposures were carried out with doses of X-rays which approximately matched those of the mustard gas in respect of their ability to produce sex-linked lethals. The results are summarized in the accompanying table.

The observations bear out the previous genetical and cytological findings. In the overall rosult, as well as at each dosage-level, there is a marked shortage of re-arrangements in the mustard-gas series as compared with the X-ray one. The overall difference between 7.6 per cent re-arrangements in the $\mathrm{X}$-ray series and $\mathbf{1} \cdot \mathbf{3}$ per cent in the mustard gas series is significant at the $0 \cdot 1$ per cent level. The results are not sufficient to decide whether, as the table suggests, the ratio between the two frequencies tends to shift in favour of irradiation as the dose is increased. If this should be true, it would indicate a difference in the mechanisms by which these two mutagenic agencies produce re-arrangements. Experiments to test this point are under way in this department.

A point worth noting is the occurrence of two reversed repeats among the eleven chemically induced structural changes. No repeat occurred among the forty-eight radiation-induced changes; in general, repeats appear to be rare after radiation treatment. The occurrence of two of them in a very small sample of chemically induced changes is remarkable. It is, however, in line with the observation made by Auerbach that a high proportion of visible mutations induced by mustard gas occur first as mosaies in the progeny of treated males ; for repeats, like mosaics, are changes which must have arisen after the treated chromosome had separated into its daughter chromatids.

\section{Institute of Animal Genetics,}

\section{Mehtab}

University, Edinburgh 9.

$$
\text { Aug. } 27 .
$$

'Auerbach, C., and Robson, J. M., Proc. Roy. Soc. Edin., B, 62, 271 (1947).

'Slizynska, H., and Slizynski, B. M., Proc. Roy. Soc. Edin., B, 62, 234

Auerbach, C., and Moser, H., Experientia, 7, 341 (1951).

${ }^{4}$ Auerbach, C., Proc. Roy. Soc. Edin., B, 62, 211 (1946).

\section{Chemical Constitution of the L-Forms of Bacteria}

THe $L$-forms of bacteria, a study of which has been described recently ${ }^{1}$, are dwarf organisms derived from a complex transformation of bacteria, either spontaneously or under various noxious influences. Their morphological as well as biological characters are so different from those existing in the bacteria they are derived from that it seemed interesting to us to compare the chemical constitution of these two forms of the same organism.

The material used for our chemical study was $L$-forms of Proteus ( $P$ 18), three to four weeks old, grown on a liquid medium ${ }^{2}$. The $L$-forms are separated from the medium by centrifugation, washed twice in physiological serum, then in distilled water, concentrated by centrifugation at 12,000 r.p.m. and resuspended in distilled water. It is emphasized that this material is not absolutely homogeneous. It consists of a mixture of about 80 per cent of $L$-forms and 20 per cent of various stages in the evolutionary cycle of these forms. We have not been able, so far, to get rid of these intermediate forms; nevertheless, we do not think that this would affect seriously the relative value of our results.

The comparative estimation of nitrogen and phosphorus shows that the nitrogen content is higher in the normal Proteus than in the $L$-forms, while the phosphorus content, on the contrary, is lower.

Treatment of the $L$-forms with cold 5 per cent trichloracetic acid gives an acid-soluble fraction, the total nitrogen of which represents about 6 per cent of the total nitrogen of the micro elements, and the phosphorus 55 per cent of the total phosphorus; under the same conditions, the normal Proteus loses about 8.5 per cent of its total nitrogen, but only 22 per cent of its phosphorus. This demonstrates in the $L$-forms an accumulation of small molecules of phosphorus compounds.

Treatment with boiling alcohol for $1 \mathrm{hr}$. and with boiling ether for $30 \mathrm{~min}$. allows the extraction of

Frfquency of Large Chromosome Re-ARrangements after Different Doses of X-RAys and of Mustard Gas

\begin{tabular}{|c|c|c|c|c|c|c|c|c|c|c|c|c|}
\hline \multirow{3}{*}{ Expt. } & \multicolumn{6}{|c|}{$\mathrm{X}$-rays } & \multicolumn{6}{|c|}{ Mustard gas } \\
\hline & \multirow{2}{*}{$\begin{array}{c}\% \text { sex-linked } \\
\text { lethals }\end{array}$} & \multirow{2}{*}{$\begin{array}{l}\text { No. larvæ } \\
\text { examined }\end{array}$} & \multicolumn{4}{|c|}{ No re-arrangements } & \multirow{2}{*}{$\begin{array}{l}\% \text { sex-linked } \\
\text { lethals }\end{array}$} & \multirow{2}{*}{$\begin{array}{l}\text { No. larva } \\
\text { examined }\end{array}$} & \multicolumn{4}{|c|}{ No, re-arrangements } \\
\hline & & & \multicolumn{2}{|c|}{$\begin{array}{c}\text { between within } \\
\text { chromosomes }\end{array}$} & \multicolumn{2}{|c|}{ No. ${ }^{\text {total }} \%$} & & & $\begin{array}{l}\text { betwe } \\
\text { chir }\end{array}$ & $\begin{array}{l}\text { ithin } \\
\text { es }\end{array}$ & No. & $\%$ \\
\hline$\underset{\text { IIV }}{\text { II }}$ & $\begin{array}{r}3 \cdot 2 \pm 0 \cdot 7 \\
4.6 \pm 0.9 \\
8 \cdot 0 \pm 1 \cdot 2 \\
10 \cdot 4 \pm 1 \cdot 3\end{array}$ & $\begin{array}{l}172 \\
162 \\
137 \\
165\end{array}$ & $\begin{array}{r}1 \\
4 \\
5 \\
13\end{array}$ & $\begin{array}{r}1 \\
7 \\
2 \\
15\end{array}$ & $\begin{array}{r}2 \\
11 \\
7 \\
28\end{array}$ & $\begin{array}{r}1 \cdot 1 \\
6 \cdot 8 \\
5 \cdot 1 \\
16 \cdot 9\end{array}$ & $\begin{array}{r}3 \cdot 7 \pm 0.6 \\
1.1 \pm 0.8 \\
7 \cdot 1 \pm 1 \cdot 1 \\
15 \cdot 0 \pm 4 \cdot 0\end{array}$ & $\begin{array}{l}195 \\
234 \\
216 \\
177\end{array}$ & $\begin{array}{l}0 \\
4 \\
0 \\
0\end{array}$ & $\begin{array}{l}0 \\
1 \\
1 \\
5\end{array}$ & $\begin{array}{l}0 \\
5 \\
1 \\
5\end{array}$ & $\begin{array}{l}0 \\
2 \cdot 1 \\
0 \cdot 5 \\
2 \cdot 8\end{array}$ \\
\hline & & 636 & 23 & 25 & 48 & $7 \cdot 6$ & & 822 & 4 & 7 & 11 & $1 \cdot 3$ \\
\hline
\end{tabular}

